\title{
$\mathrm{X}$ 염색체와 1 번 염색체간 균형전위와 동반된 강직척추염
}

\author{
김령훈, 이정욱
}

부산성모병원 내과

\section{Ankylosing spondylitis associated with balanced reciprocal X-1 translocation}

\author{
Young Hoon Kim, Jung Ouk Lee \\ Department of Internal Medicine, Busan St. Mary's Hospital, Busan, Korea
}

\begin{abstract}
A number of research papers have reported more frequent occurrence of rheumatic/autoimmune disease among patients with hypogonadism or a chromosomal anomaly with potential X-chromosome defects. A 30-year-old female patient came to the hospital with a main cause of bilateral buttock pain, which began two years ago and worsened seven days ago. Ankylosing spondylitis with invasion of both sacral-iliac joints was observed. On magnetic resonance imaging, although the uterus was observed normally, an ovary was not observed. In a chromosome test, balanced reciprocal X-1 translocation of $46, X, t(X ; 1)(p 10 ; q 10)$ was diagnosed. Here, we report on the first case involving ankylosing spondylitis accompanied by balanced reciprocal X-1 translocation.
\end{abstract}

Keywords: Ankylosing spondylitis; Genetic translocation; Hypogonadism

\section{서 론}

$\mathrm{X}$ 염색체와 상염색체간 균형전위(balanced X-autosome translocation)는 X염색체와 $1,3,4,6,9,12,15,18,22$ 번 상염색체와의 전위가 보고되었으며, 특히 X염색체와 1 번염 색체간 균형전위(balanced reciprocal X-1 translocation)는 전 세계적으로 7개만의 증례가 발표될 정도로 희귀하다[1]. 국 내 문헌 중 $\mathrm{X}$ 염색체와 상염색체간 균형전위에 대한 증례는 $\mathrm{t}(\mathrm{X} ; 14)(\mathrm{p} 11.4 ; \mathrm{p} 12)$ 와 남성불임에 대한 하나의 증례 뿐이다[2].

$\mathrm{X}$ 염색체와 상염색체간 균형전위는 생존 출생아 10,000 명 당 1-3명 꼴로 발생하며, 임상양상이 다양하게 관찰된다[3].

Received: July 6, 2015, Revised: August 29, 2015

Accepted: September 8, 2015

Corresponding Author: Jung Ouk Lee, Department of Internal Medicine, Busan St. Mary's Hospital, 23 Yongho-ro, 252beon-gil, Nam-gu, Busan 48575, Korea Tel: +82-51-933-7237, Fax: +82-51-932-8600

E-mail: cocoabing@gmail.com
Waters 등은 1983년부터 1997년까지 X염색체와 상염색체 간 균형전위를 가지는 여성을 대상으로 후향연구를 실시하 였으며, 그의 연구에 따르면 X염색체와 상염색체간 균형전 위는 4 가지 임상양상으로 분류된다. 표현형은 정상이나 반복 되는 유산의 병력이 있는 경우, 생식샘저하증(hypogonadism) 의 형태를 보이는 경우, 명확한 X연관열성/우성장애(well-defined X-linked recessive or dominant disorders)를 가지는 경 우, 선천성 불구와 학습장애를 포함한 발달지연을 가지는 경우이다[4]. 그 중 $35 \%$ 에 해당되는 생식샘저하증과 류마티 스자가면역질환이 동반된 증례가 드물지만 보고되고 있다.

저자들은 $\mathrm{X}$ 염색체와 1 번염색체간 균형전위와 류마티스 자가면역질환 중의 하나인 강직척추염이 동반된 예를 경험 하였기에 보고하는 바이다.

\section{증 례}

환 자: 여자, 30 세

Copyright (C) 2017 Yeungnam University College of Medicine

This is an Open Access article distributed under the terms of the Creative Commons Attribution Non-Commercial License (http://creativecommons.org/licenses/by-nc/4.0/) which permits unrestricted non-commercial use, distribution, and reproduction in any medium, provided the original work is properly cited. 
주 소: 7일전부터 악화된 양측 골반통증

현병력: 2년 전부터 양측 골반통증이 발생되었고, 7 일 전 부터 그 증상이 악화되어 본원에 내원하였다. 통증은 아침에 특히 심하고 일어나 움직이면 호전되는 양상이었다.

과거력: 17 세까지 월경이 시작되지 않았으며, 그 당시 혈액 검사상 터너증후군으로 추정 진단 후 에티닐에스트라디올 (ethinyl estradiol)을 지속 복용하였다. 투약 후에는 월경이 정상적으로 발생하였다고 한다.

가족력: 특이소견 없음.

진찰 소견: 활력징후는 혈압 $110 / 70 \mathrm{mmHg}$, 맥박 72회/분, 호흡수 20 회/분, 체온 $36.5^{\circ} \mathrm{C}$ 였으며 신체검사에서 신장은 $175 \mathrm{~cm}$, 몸무게는 $68 \mathrm{~kg}$ 이었다. Schober test는 $3.5 \mathrm{~cm}$ 였다.

검사실 소견: 전혈구 검사에서 백혈구 $10,250 / \mu \mathrm{L}$ (호중구 $71.6 \%$, 림프구 $19.3 \%$, 단핵구 $5.1 \%$, 호산구 1.9\%, 호염구 $0.5 \%)$, 혈색소 $11.1 \mathrm{~g} / \mathrm{dL}$, 혈소판 $249,000 / \mu \mathrm{L}$ 였다. 간기능 검 사에서 아스파르테이트아미노전이효소 $14 \mathrm{U} / \mathrm{L}$, 알라닌아미 노전이효소 $12 \mathrm{U} / \mathrm{L}$, 총단백질 $6.3 \mathrm{~g} / \mathrm{dL}$, 알부민 $3.6 \mathrm{~g} / \mathrm{dL}$ 였으 며, 신장기능검사에서 혈액요소질소 $13 \mathrm{mg} / \mathrm{dL}$, 크레아티닌 $0.8 \mathrm{mg} / \mathrm{dL}$ (사구체여과율 $88 \%$ ) 였다. 갑상선 기능검사는 정 상이었으며, 적혈구침강속도(erythrocyte sedimentation rate, ESR) $62 \mathrm{~mm} / \mathrm{hr}$, C-반응단백질(C-reactive protein, CRP) 99.57 $\mathrm{mg} / \mathrm{L}$ 로 상승하였다. 면역학적 검사에서 류마티스 인자, 항핵 항체 검사에서는 음성이였으며, 사람백혈구항원(human leukocyte antigen, HLA) 검사에서는 HLA-B27 항원 양성이었 다. 염색체 검사에서는 상호전완전위(reciprocal whole-arm translocation) (46,X,t(X;1)(p10;q10))이 관찰되었다(Fig. 1).

방사선 소견: 단순천장관절 $\mathrm{X}$ 선 검사에서는 양측 천장관 절을 침범하는 연골하 미란성 변화와 경화(subchondral erosion with sclerosis)가 관찰되었다(Fig. 2). 골반 자기공명영상 (magnetic resonance imaging, MRI)에서 자궁은 정상적으로 관찰되었으나, 자궁원삭(round ligament)과 난소가 관찰되 지 않았다. 지방억제T2강조영상(fat-suppressed T2-weighted image)에서 천장관절에 우측 연골하 골수(subchondral bone marrow)의 강영상(hyperintensity)과 좌측 연골하 골수의 저 영상이 관찰되었고, 이는 각각 천장관절의 급성 염증과 경화 를 의미한다. 그리고 양 천장관절의 표면은 균일하지 않고 미란들이 관찰되었다(Fig. 3).

치료 및 경과: 휴식으로 나아지지 않는 3 개월 이상 지속된 염증성 허리통증, 혈액검사상 CRP, ESR이 상승, HLA-B27항 원 양성이었으며, 방사선 소견상 천장관절에 연골하 미란성 변화와 경화 및 급성 염증이 관찰되어 강직척추염으로 진단
하였다. 하지만 포도막염(uveitis), 건선(psoriasis), 염증성 장 질환(inflammatory bowel disease) 등의 강직척추염의 관절 외 증상은 관찰되지 않았다. 술파살라진(sulfasalazaine), 비스 테로이드성 소염진통제(nonsteroidal antiinflammation drugs), 프레드니솔론(prednisolone)으로 치료를 시작하였으며, 증 상이 호전되면서 $\mathrm{ESR}, \mathrm{CRP}$ 도 정상수치로 관찰되었다. 약물 복용 중 임상 증상, $\mathrm{ESR}, \mathrm{CRP}$ 수치가 악화되어 에타너셉트 (etanercept) $50 \mathrm{mg}$ 을 주 1회 피하주사로 바꾸어 치료하였으 며, 이후로 현재까지 특별한 증상 호소 없이 외래에서 추적 검사 중이다.

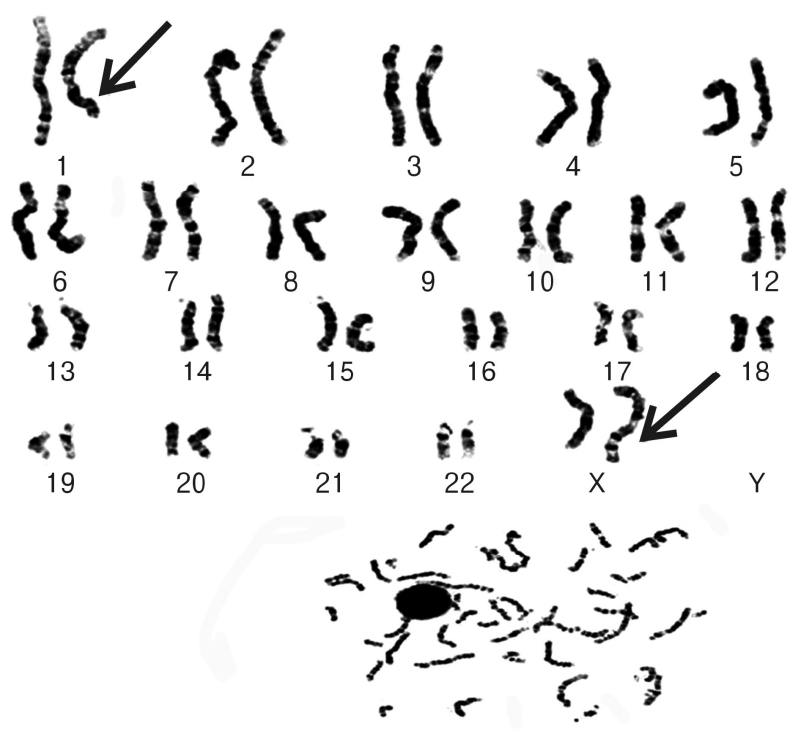

Fig. 1. According to the chromosome test using blood, reciprocal whole-arm translocation of X chromosome p10 and chromosome 1 q10 was observed around the centromere.

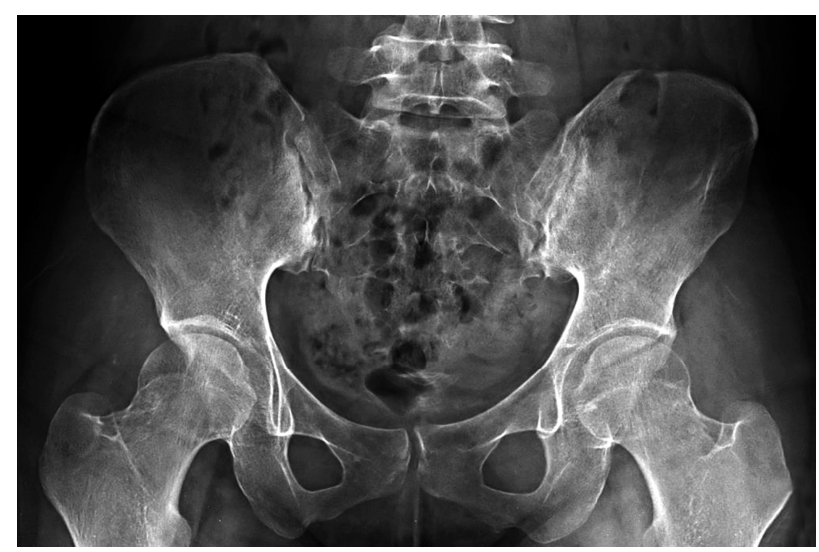

Fig. 2. Anterior-posterior view of sacroiliac joints shows subchondral erosion with sclerosis in both sacroiliac joints. 


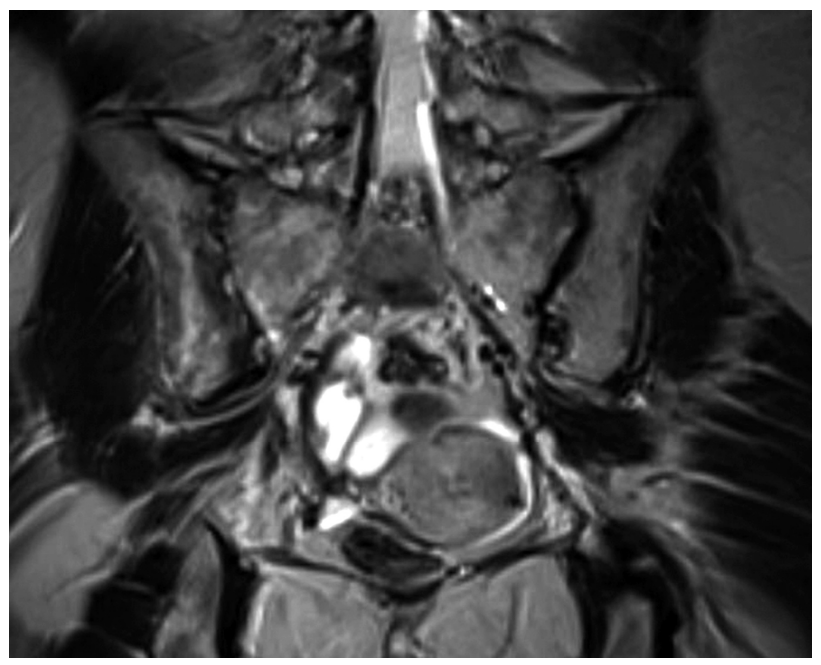

Fig. 3. Coronal fat-suppressed T2-weighted magnetic resonance imaging of sacroiliac joints show hyperintensity of the right subchondral bone marrow suggestive of active inflammation and subchondral hypointensity of the left indicative of sclerotic change. There are also irregularities and erosions of the joint surface on both sides. The uterus was observed normally, but the round ligament and ovary were not observed.

\section{고 찰}

강직척추염은 주로 축골격을 침범하는 염증성 질환이며, 염증성 허리통증, 비대칭성 소수성 관절염(oligoarthritis), 부 착부염(enthesitis)의 형태로 나타난다. 관절 외 증상으로 포 도막염, 건선, 염증성 장질환과 같은 질환이 발생할 수 있고, 남성에서 발생 빈도가 높으며, 젊은 나이에 발병할 경우 기능 적 예후가 나쁜 것으로 알려졌다.

강직척추염의 발생에는 유전적 소인이 매우 강하게 작용하 는데, 주조직적합복합체(major histocompatibility complex) 인 HLA-B27 항원, HLA-B60 항원, HLA-DR1 항원과 연관되 어 있는 것으로 밝혀졌다. 특히 강직척수염 환자의 $90-95 \%$ 에서 HLA-B27 항원 양성이 관찰되고, HLA-B27항원이 양성 일 때 이 질환의 발생위험이 $5 \%$ 상승하는 연관성으로 살펴볼 때 HLA-B27 항원이 중요한 유전자인 것으로 생각된다[5].

그리고 HLA-B27 항원 이외 인터루킨-23 수용체(interleukin-23 recepter), 세포질그물 아미노펩티다제 1,2 (endoplasmic reticulum aminopeptidase 1,2 )도 강직척추염과 관련된 유전자들로 밝혀지면서 유전체 관련 병태생리 및 표적 치료 연구가 진행되고 있다. 하지만 임상적 특징에 부합되지 않고 골 형성과 관련된 병태생리의 이해는 아직 불분명하다[6].

Hoyle 등은 강직척추염이 남성에서 발생 빈도가 높고 환 자의 가족들에서 더 빈번하므로 유전적 인자가 강직척추염
발생과 연관이 있으며, 강직척추염이 X염색체 열성 질환이 라는 가설을 세웠다. 이에 234명의 형제자매들을 대상으로 강직척추염과 $\mathrm{X}$ 염색체와의 연관성에 대해 연구를 하였으나 강직척추염과 $X$ 염색체간의 직접적인 유전적 관계가 없었다 고 보고하였다[7].

현재까지 $\mathrm{X}$ 염색체와 1 번염색체간 균형전위와 강직척추 염이 동반된 경우는 보고된 바가 없다. 하지만 국외에 보고된 2 례에 따르면 강직척추염과 $\mathrm{X}$ 염색체와 상염색체간 균형전 위에서 나타날 수 있는 생식샘저하증이 관련이 있다고 보고 되었다.

Onose 등의 보고에서는 30명의 강직척추염 환자를 생식 선, 관절염의 두 가지 측면으로 조사하였으며, 그 중 강직척추 염의 활성도와는 관련 없이 테스토스테론의 농도가 의미 있 게 낮은 것으로 나타났다. 이는 생식샘저하증의 대표적인 임상양상과 일치하는데, 이를 토대로 그들은 생식샘저하증 을 강직척추염의 유발 배경으로 결론지었다[8]. JiménezBalderas 등의 연구에서는 치료받지 않은 생식샘저하증이 있 는 남성 13 명 중 8 명에서 류마티스/자가면역질환이 관찰되 었다. 그 중 강직척추염 4명, 전신홍반루푸스(systemic lupus erythematosus) 2 명, 소아류마티스관절염(juvenile rheumatoid arthritis) 1 명, 소아피부근육염(juvenile dermatomyositis) 1 명으로 강직척추염의 빈도가 가장 높았다. 강직척추염이 진단된 4명은 모두 HLA-B27 양성이었고, 생식샘저하증의 원인은 칼만증후군(Kallmann's syndrome)이 2명, 클라인펠 터증후군(Klinefelter's syndrome)이 1명, 고환 암으로 양측 고환절제술을 시행 받은 1 명이었다. 류마티스/자가면역질환 이 있는 환자들은 테스토스테론, 에스트라디올 $17 \beta$ 수치가 둘 다 낮았지만, 테스토스테론 수치가 더 의미 있게 낮았다. 이 연구에서는 생식샘저하증 자체와 현저히 낮은 테스토스 테론 농도가 류마티스/자가면역질환의 높은 빈도와 연관이 있다고 보고하였다[9].

본 증례의 환자는 17 세에 또래에 비해 초경이 늦은 증상으 로 타 병원에서 터너증후군으로 추정 진단 하에 에스트로겐 제제를 복용하여 정상적인 월경이 발생하였다. 이후 허리통 증이 3개월 이상 지속되어 본원을 내원하였으며, 골반 자기 공명영상에서 천장관절에 연골하 미란성 변화와 경화 및 급 성 염증이 관찰되어 강직척추염이 진단되었으며, 선천성 불구 나 발달지연 및 가족력이 없음에도 불구하고 자궁원삭, 난소 가 관찰되지 않고 초경이 늦은 점 등으로 미루어 생식샘저하 증이 의심되었다. 이후 시행한 염색체 검사에서 X염색체와 1 번염색체간 균형전위가 진단되었으며, 이로 인해 생식샘저 
하증의 임상양상이 발생된 것으로 생각된다. 이 증례를 토대로 저자들은 희귀하기는 하지만 강직척추염과 $\mathrm{X}$ 염색체와 1 번 염색체간 균형전위간의 관계에 대한 의문을 제기하게 되었다.

국내문헌 중 생식샘저하증과 관련된 강직척추염은 2예로 1 차성 생식샘저하증과 터너증후군에 대한 보고가 있었으나 직접적으로 $\mathrm{X}$ 염색체와 1 번염색체간 균형전위와 병발된 증 례는 없었다[10,11]. 국외문헌에서 생식샘저하증과 류마티 스/자가면역질환에 대한 연구들을 보면 강직척추염과 X염 색체는 직접적, 유전적인 연관이 없다고 하였지만 X염색체 와 1 번 염색체간 균형전위에서 관찰될 수 있는 생식샘저하증 과 강직척추염의 발생에 연관성이 있다는 연구도 있었다 [7-9]. 하지만 생식샘저하증과 강직척추염이 동반된 증례가 매우 드물어 생식샘저하증에 동반된 강직척추염이 일반적으 로 발생한 강직척추염과 비교하여 우세한 임상양상이나 병 의 진행 양상, 치료에 대한 반응 등에 대해서는 알려진 바가 없다. 강직척추염의 병인은 HLA-B27과 같은 유전적 요인 이외에는 아직 밝혀진 것이 없고, 이마저도 명확한 메커니즘 을 설명하기가 어렵다. 환경적 요인 또한 강직척추염의 병인 이 될 수 있겠지만 현재까지의 연구에서 아직 구체적으로 밝혀진 것은 없다. X염색체와 1 번염색체간 균형전위는 아주 드문 염색체 이상으로 그 수가 적어 강직척추염이 병발된 본 증례만으로는 두 질환이 우연히 병발했는지, 병인론적 연관성이 있는지를 판단하기는 어렵다. 하지만 생식샘저하 증 환자에서 강직척추염 발생이 높은 것은 아직 병인이 명확 하지 않은 강직척추염에 있어 그 병인을 밝히는데 분명한 도움이 될 수 있다고 생각한다.

\section{CONFLICT OF INTEREST}

No potential conflict of interest relevant to this article was reported.

\section{REFERENCES}

1. Duhan N, Malik R, Upadhyaya M. Balanced reciprocal X-1 translocation $(46, \mathrm{X}, \mathrm{t}(\mathrm{X} ; 1)(\mathrm{q} 22 ; \mathrm{p} 32)$ and primary amenorrhea. Eur J Obstet Gynecol Reprod Biol 2014;181:338-9.

2. Hwang SH, Lee SM, Seo EJ, Choi KU, Park HJ, Park NC, et al. A case of male infertility with a reciprocal translocation t(X;14)(p11.4;p12). Korean J Lab Med 2007;27:139-42. Korean.

3. Binkert F, Spreiz A, Höckner M, Miny P, von Dach Leu B, Erdel $\mathrm{M}$, et al. Parental origin and mechanism of formation of a $46, X, \operatorname{der}(\mathrm{X})(\mathrm{pter} \rightarrow \mathrm{q} 21.1:: \mathrm{p} 11.4 \rightarrow \mathrm{pter}) / 45, \mathrm{X}$ karyotype in a woman with mild Turner syndrome. Fertil Steril 2010; 94:350.e12-5.

4. Waters JJ, Campbell PL, Crocker AJ, Campbell CM. Phenotypic effects of balanced X-autosome translocations in females: a retrospective survey of 104 cases reported from UK laboratories. Hum Genet 2001;108:318-27.

5. Braun J, Sieper J. Ankylosing spondylitis. Lancet 2007;369 (9570):1379-90.

6. Tsui FW, Tsui HW, Akram A, Haroon N, Inman RD. The genetic basis of ankylosing spondylitis: new insights into disease pathogenesis. Appl Clin Genet 2014;7:105-15.

7. Hoyle E, Laval SH, Calin A, Wordsworth BP, Brown MA. The X-chromosome and susceptibility to ankylosing spondylitis. Arthritis Rheum 2000;43:1353-5.

8. Onose G, Pereţianu D, Zaharescu J, Moţoiu S. Correlations between spondylarthropathic inflammatory troubles and gonadal (androgenic) troubles in men. Study on 30 cases with a new methodological analysis. Rom J Intern Med 1995;33: 93-111.

9. Jiménez-Balderas FJ, Tápia-Serrano R, Fonseca ME, Arellano J, Beltrán A, Yáñez P, et al. High frequency of association of rheumatic/autoimmune diseases and untreated male hypogonadism with severe testicular dysfunction. Arthritis Res 2001;3:362-7.

10. Jun BY, Lee GJ, Kim JH, Lee JM, Chang SA. Primary hypogonadism associated with ankylosing spondylitis. J Korean Endocr Soc 2008;23:352-7. Korean.

11. Kim YS, Jeong YJ, Kim HS. A case of ankylosing spondylitis associated with Turner's syndrome. J Rheum Dis 2011;18: 208-11. Korean. 